\title{
Shiraliyeva S.J.•
}

DOI: 10.25108/2304-1730-1749.iolr.2016.49.130-146

\section{Integrative tactics of identification of persons and items}

\begin{abstract}
It is considered a content of measures on preparation and conducting of identification of persons and items.

There studied the factors influencing in process of memorization, remember and reproduction of an identifier, it is analyzed the ways of checking of social, temporal and spatial orientation of an identifier. Practical recommendations are given.
\end{abstract}

Keywords: tactics of identification; psycho-physiological particularities of a person; signals of emotional excitement; diagnostics.

According to Article 239 of the Code of Criminal Procedure (hereinafter, the $\mathrm{CCP}$ ) of Azerbaijan Republic, when necessary to bring any person to identification to witness, victim, suspected and accused, an investigator interrogates them concerning appearance and features of the person, and on circumstances, at which identifier saw identified person and draws appropriate record. In the same order and same cases is produced an identification of items (Art. 240 of the CCP).

Both identification of a person and identification of items have to precede a preparatory work an investigator, one of the elements of which is preparation of identifier.

Under preparation of an identifier is understood a complex of techniques of an investigator directed in providing optimal psycho-physiological state of an identifier person in moment of bringing for identification. Preparation of an identifier includes a usage of the techniques directed to providing normal

\footnotetext{
- Shiraliyeva Sabina Javanshir qyzy - PhD in Law, a member of Council of International Organization for Legal Researches (Azerbaijan). E-mail: mopi_sid@yahoo.com
} 
functioning of a person in situations of investigation and the techniques of impact in behaviour and state of an identifier [2, p. 25].

Most part of the identifiers with different extent of deepness test a state of discomfort due to unusual environment, necessity of limitation of movement's freedom, violation of typical rhythm of life, fear of uncertainty, ahead of the future, before the ambiguity of his role in a current situation for himself and his close due to chosen role of an accuser; apprehensions and self-doubts in reality, the feasibility of his commitments, fear of failure; contradictoriness of assessment of similar actions in micro-group, in environment of the identifier and requirements to fulfill a citizen duty; possible feeling of pity to himself and to identified person and associated with this increasing of emotional perception, anxiety. Listed factors influences in the end results of bringing for identification since, as it known, this investigative action is based on possibilities of usage of the mechanisms of man's memory. The investigator's task in this situation is to conduct such psychological preparation of interrogated person, which could be sufficiently reduce negative effect of impact of external irritants [3, p. 17-20].

Content of an investigator's measures on preparation of an identifier is determined with temporal opportunities of the investigator and environment of investigation in specific stage. The task of preparation might only be resolved upon absence of conflict situation.

To the techniques of preparation directed to ensuring of normal functioning of signs of a person are related:

- establishing of psychological contact to concrete person as an optimal form of interaction. Psychological contact serves one of the components, which renders a positive influence into an identifier since during identification he finds psychological support just in an investigator. Investigator is an indicator of social assessment of behaviour of an identifier [3, p. 29].

- right choice by investigator the time of performance of investigative action in a moment of the best psych-physiological state of concrete identifier. Psychological survey showed that there are three stages of man's working capacity: 
inclusion in a work, period of high work capacity and its falling due to development of tiredness. It is essentially that impacts in all parameters of personal characteristics of man, important for cognitive activity. In addition, there are periods during a day, when an individual achieves high level of work capacity. Often, this is related with established in process of working activity a stereotype of behaviour. These data is subject to clear and to use at planning of conducting a bringing for identification [6, p. 455-461].

To logical and psychological techniques used by an investigator at production of identification of persons and items are related a determination of right content of external manifestations of an identifier and other his psycho-physiological particularities [11, p. 101].

While determining the right content of external manifestations of an identifier it is necessary to take into account his sex, physical defects, age, mimics, voice and speech.

So, in result of made research testify that about $80 \%$ of men suffer with defects of colour-perception, i.e. do not distinguish red and green colours; at the same time, there is no much colourful blindness among women. In addition, women keep in mind perceived earlier information better than men [9, p. 313-322].

Often, physical defects seriously change psychics of an individual, up to formation of pathological development. In addition, defects in the organs of sight, hearing and others can be compensated for account of extension of opportunities of other organs. For instance, at absence or reduction of sight can be become more sensitive a hearing, smell, and touch. The unnatural fullness and thinness of a body can serve as a sign of deviations in a psyche linked with abnormal changes on demands and motivation.

Age particularities essentially influence into ability of person to identification: from one side, with age, the sight and hearing can be impaired and from other side - gained with years an empirical experience allows more rightly perceive and assess, and also verbally describe received information [11, p.102]. 
Mimicry is a main means of diagnosing of states. Totality of mimic particularities of an individual that corresponds to the states of sadness, anger, joy, fear, etc., is a signal of these states. Mimic expressions must correspond to situation, in which an interrogated is. Arisen here inconsistencies should be explained by an investigator. Pantomime is manifested in gestures, posture and typical poses. Gesticulation is characteristic for specific environment, in which an interrogated person lives. Restraining of usual gesture for oneself causes a person's inhibition, cramping, a feeling of discomfort. A normal gesture for a particular person can also carry a significant informational content, supplementing oral speech. If gesture contradicts mimics and other manifestations of man then it may testify about pathological states, for instance, on alcohol or drug intoxication [9, p. 313-322].

Posture gives a human figure a common appearance and depends on the usual position of a body and head. It can be straight, stooped, hunched, lethargic and vigorous.

To a certain extent a posture of an individual can affect his mental state. For example, a person sitting in a rest chair feels himself freer, more relaxed than those sitting on a chair or stool.

Voice is distinguished on pitch, timbre, manner of pronunciation, training nature. Vocal characteristics of a voice are largely related to an emotional state of interrogated person. Strengthening or reducing of voice volume, changing of its timbre, pauses, coughs etc. in combination of mimics show a level emotional tension of an individual.

Unusual state of interrogated might be confirmed with breaches of a speech, signs of which are: continuous speech without participation of interlocutor and reactions on his remarks, unsystematic change of topics; reiteration fully of partly the same thought, when a man cannot "come off" of said; disruptiveness, disconnectedness, absence of meaningful content of speech at it right grammatical designing; extreme itemization of speech; fruitless and baseless reasoning [4, p. 315-329]. 
To determination of other psycho-physiological particularities an identifier is related identification of professional skills, checking of right social, temporal and spatial orientation, normal for the person the emotional manifestations and tension on voice and speech, particularities of sight, ability to colour-perception and hearing.

Professional skills essentially influence in an opportunity of memorization and reproduction of information. In addition, profession actively impacts on formation of human memory types (visible and figurative, verbal and logical, visual, motional, and emotional). Determination of the memory type give a chance to an investigator to assist of an interrogated person in reproduction of interested information [11, p. 104].

Checking of right social, temporal and spatial orientation of an individual is carried out with formulation of questions associated with questionnaire part of record that allows making initial conclusions. So, being interested where from an interrogated came to a place of investigative action and how much time was spent to the way, whether quick the questioning place found, it might be compared responses with personal experience and thus to determine opportunities of interrogated in assessment of time's and spatial intervals, and his ability to orientation [7, p. 90].

The way of detection a normal emotional manifestations of person is to say to interrogated emotionally significant for him information at initial stage of questioning. Few words about weather said by investigator will help to detect mimic and speech expressions of satisfaction or displeasure. Thus, there detected individual signs of manifestations of concrete person, changing of which later informs investigator about goals' achievement in course of impact on interrogated [8, p. 435-450].

Signals of emotional excitement might be difficulties in formulating of thoughts, a choice of the words for their expression, which is affected in appearance of searching and describing gestures, increasing of number of pauses, searching words, repetitions etc. Conscious control over speech is weakened, the 
number of the word-parasites, standard sets of words is increased. The latter is pronounced in higher temp tempo than in speech at usual state. It is essentially increased number of non-communicative gestures, which are not recognized by a speaker. Herewith a dictionary of oral speech getting poor, becomes stereotypical. An emergence of emotional intensity signals requires an immediate reaction of an investigator to determine its causes and take actions for control over situation [1, $\mathrm{p}$. 11].

Ways of reading and signing of a record might be testified about sight's particularities of an individual. Despite weak sight, some people hesitate to wear glasses, and sometimes they have no them. Naturally, presence of sight's defects make them to move up (myopia) or away (hyperopia) a record to the eyes over usual that may serve for investigator appropriate signal. The same parameters might be determined by a way of record signing. Badly seeing individual make a signature either unjustifiably small, or too large, and, sometimes not there it should be done. It is necessary to look attentively to eyes' cornea of questioning person since he can have contact lenses. At signing of questionnaire art of a record, reading of rights and duties it is necessary to watch his ability to speed reading since this characterizes attentiveness, and sometime his interest in case's outcome, ability to assimilate read information and its memorization [11, p. 105].

An issue of determination of colour-perception by identifier might be solved with set of four colour felt-tip pens or ball pens (red, green, blue, and black). At signing of questioning part of record an interrogated person might be brought the set in one box and asked to sign by red in one place and green in other one $[5, \mathrm{p}$. 89-102].

In course of filling of questionnaire data it may ask some questions lower of usual and thus to check his hearing.

At discovering of signs of possible mental disease or serious psychic abnormalities it is not excluded an opportunity to conduct investigatory actions with participation of this person, including bringing for identification. Data received should be carefully taken in account when planning and conduct 
investigative actions, and also at evaluation their results. Decision about conducting identification is accepted with considering of person's state that established at his second interrogation with participation of specialist. Data fixation by investigator that received in result of criminalistical express-diagnosis is carried out both with verbatim fixation in a record of emotional and evaluation expressions, questions and responses etc. and audio and video records. Fixed data is a basis for assignment of expert examination, conducting of identification and making other procedural decisions.

Impact on an identifier at conducting identification should be made in strict frames of the law. It is not allowed to get testimonies through application of physical violation, threats and other unlawful methods. In addition, an impact on identifier should not be influenced in a content his testimonies and freedom of conducting a choice of identified object during identification. It should keep in mind that effect of impact is increased in unknown situation, in new environment, and also at conducting of significant task, i.e. in conditions are inherent to conducting of identification and therefore the techniques of impact need to apply carefully [10, p. 76-78].

Impact might be fulfilled in form of orders, requirements, requests, reproaches, suggestions, advice, warnings and preventions.

It is reasonable to explain to identifier typical order of identification and give clear definitions all elements of its actions. Wherein an identifier The identifier is accustomed to an environment in which he needs to act, he is formed a formulation for identification of known object, mental solution of a task about his actions, overcome negative influence of technical fixation devices in identifier [11, p. 107].

\section{References}

1. Bodalev A.A. Vospriyatie cheloveka chelovekom [Perception of man by man]. Leningrad, 1965, 200 p. 
2. Vasilyev A.N. Problemi metodiki rassledovaniya otdel'nikh vidov prestuplenii [Issues of investigation's methods of separate kinds of crimes]. Moscow, 2002, 72 p.

3. Gapanovich N.N. Opoznanie v sledstvennoi i sudebnoi praktike (taktika) [Identification in investigative and judicial practice (tactics)]. Minsk, 1978, 176 p.

4. Zimbardo F., Lyayppe M. Sotsial'noe vliyanie [Social influence]. S. Petersburg, 2000, 148 p.

5. Konovalova V.E. Pravovaya psikhologiya [Legal psychology]. Kharkov, 1997, 198 p.

6. Kriminalistika [Criminalistics]. Uchebnik. pod red. Yablokova N.P. [Textbook ed. by Yablokov N.P.]. Moscow, 2000, 781 p.

7. Mansurov R.M. Opyt issledovaniya vremennikh porokov adekvatnogo zritel'nogo vospriyatiya tsifr $\mathrm{v}$ zavisimosti ot ikh ugolovnogo razmera $\mathrm{i}$ osvescheniya [Experience of examination of defects of adequate of visual perception of figures in dependence on their angle size and lighting]. Sb. Problemy obschey sotsial'noy i inzhenernoy psikhologii [Collection of Problems of common social and engineering psychology]. Leningrad, 1965, pp. 88-94.

8. Nemov R.S. Psikhologiya [Psychology]. V 3 knigakh [in 3 books]. Moscow, 2001, 640 p.

9. Ratinov A.R. Sudebnaya psikhologiya dlya sledovateley [Forensic psychology for investigators]. Moscow, 2001, 290 p.

10. Smirnov A.A. Problemy psikhologii pamyati [Issues of memory's psychology]. Moscow, 1966, 422 p.

11. Shiraliyeva S.J. Logiko-psikhologicheskie priemy, ispol'zuemye sledovatelem pri proizvodstve opoznaniya lits i predmetov [Logical psychological techniques used by investigator at production of identification of persons and itmes]. Sbornik nauchnykh statey. Nauka i obrazovanie [Collection of scientific articles. Science and Education], no. 13, pp. 99-107. 